\title{
MOHAMMAD ARKOUN'S STUDY OF THE QURAN
}

\author{
Katharina Völker*
}

This exploration into Arkoun's stances on the Quran looks onto the genesis of the Quran, the notion of the Quran as the 'deliverer of truth', and with that, its significance for the 'being in the world' of Muslim societies. I will also point out some crucial difficulties in the study of Arkoun's views on the Quran as well as their implications for the study of Islamic cultures.

Keywords: Arkoun, Quran, revelation, hermeneutics, exegesis, haqq

* University of Otago

This research is supported by the

University of Otago Post-Graduate Research Fund. 
Mohammad Arkoun (1928 , Algeria; †2010, Paris) was an influential Muslim intellectual and particularly concerned with - amongst a profound spectrum of scholarly interests - reforming the academic study of Islamic societies. Trained at the University of Algiers (Faculty of Philology) he ventured off to lecture Arab language and literature at the Sorbonne. His engagement with philosophy and sociology led in 1968 to his $\mathrm{PhD}$ at the Sorbonne through a work on Ibn Miskawayh's ethics. ${ }^{1}$ He lectured at several universities in Europe and the USA and remained emeritus professor of history and Islamic thought at the Sorbonne until his death. Mohammad Arkoun was furthermore scientific director of the journal ARABICA (Brill: Leiden), a member of the 'French National Committee for Ethics, Weltanschauung and Health', and in 2002 a member of the international jury of the UNESCO Prize for the promotion of peace. From 2003 onwards, he held a chair within the 'Committee for Laicism in France' and was awarded the Ibn Rushd Prize for Freedom of Thought the same year in Germany.

He is known for his contributions to debating Islam and modernity, humanism, ${ }^{2}$ arguing and providing for methodological and scholarly rigour within Quranic studies, ${ }^{3}$ and for his long-term project: the critique of Islamic as well as religious reason. ${ }^{4}$ The application of concepts such as demythologization, deconstruction, rationalization and historization to the Quranic text earned him frequent accusations of heresy. However, admired by numerous students and fellow scholars, he remained academically active until his last year. He specifically contributed to platforms of interreligious dialogue and became a supporter of the 'Weltethos-Project'.

For Arkoun, the study of Muslim mentalities, Islamic cultures and philosophies, requires a reformed hermeneutics of Quranic studies:

One necessarily has to start with the Quran because, historically, everything started with what I called the "Experience of Medina", including the communication of the Quran received as revelation and the historical process through which a social group, named believers (mu'minūn), emerged and dominated other groups named unbelievers, infidels, hypocrites, polytheists ( $k \bar{a} f i r u \bar{n}$, munāfiqūn, mushrikūn). ${ }^{5}$

Arkoun's perspectives on the Quran are of suggestive character and not expressed in the affirmative manner of the devotee. Therefore it is difficult if not even impossible to deduce conclusions about his private religiosity. Some researchers have tried to do so, but I find it rather difficult und unpromising. This is because his writings on Islam and the Quran are formulated in an explicitly scientific and distanced manner. Other Muslim scholars in the West, for example Fazlur Rahman (Chicago) and Abu Zayd (Utrecht) much more obviously state their own beliefs, within their scholarly works. ${ }^{6}$ Therefore, while investigating Arkoun's thought, it seems important to distinguish between his scientific statements and what may be his own beliefs. This means that if his private views remain in the dark, his academic work should not be mistaken for his own views. Nonetheless, it is possible to extract enough material from Arkoun's writings for speculations about some of his own accounts concerning particular topics. Although of course Arkoun's scientific engagement is our main interest, I generally think it is important to evaluate how far his thought is influenced by personal beliefs. No intellectual develops her philosophy in a vacuum void of experience. In short, Arkoun's distance from affirmative expressions of what he holds true about matters of belief poses a specific challenge while studying his work.

\footnotetext{
Arkoun's PhD thesis: Traité d'Ethique, notes du Tahdhîb al-akhlâq de Miskawayh, 1st edition 1969; 2nd edition 1988.

2 Kamrava, New Voices of Islam, 29.

3 Zayd, Reformation of Islamic Thought, 86.

4 Günther, Mohammed Arkoun, 129

5 Arkoun, Rethinking Islam Today, 223.

6 Völker, Quran and Reform: Rahman, Arkoun, Abu Zayd, PhD diss., University of Otago, New Zealand.

http://otago.ourarchive.ac.nz/handle/10523/2245. Here I compare Arkoun's thought on the Quran, its exegesis and his hopes for various dimensions of social and academic reform with similar concepts offered by the two scholars Fazlur Rahman and Nasr Hamid Abu Zayd.
} 
Arkoun's scientific engagement with Islam reveals his main interest: the analysis of Quranic interpretations and their applications throughout Islamic history. Arkoun expresses preferences for and rejections of certain treatments of the Quran. Highlighting these preferences could show what Arkoun holds expressible about the Quran and which research and interpretation methods he finds suitable. In order to extract his preferences I need to find out how Arkoun understands the nature of the Quran. More specifically I am interested in how Arkoun might want the Quran to be understood and treated today.

\section{A Product of Selection and Distortion}

From an explicitly claimed anthropological viewpoint, ${ }^{7}$ Arkoun is particularly critical with three ideas of Islamic accounts of the Quran: the belief in the Quranic text as being God's words per se (ipsissima verba); secondly the idea of this word's preservation on a heavenly tablet; ${ }^{8}$ thirdly, the exceptionality of the memories of the followers (sahāba) of Muhammad which preserved the verses as uttered by Muhammad. ${ }^{9}$ Arkoun admits that the Quran was (possibly) partially written down during the lifetime of the Prophet and until the compilation process under 'Uthman began, various partial compilations circulated. ${ }^{10} \mathrm{He}$ might be alluding to an idea derived from hadith material stating that one of Muhammad's companions, Zayd b. Thabit, ${ }^{11}$ "used to write down the revelations for the Prophet." ${ }^{12}$ Then the written accounts of the Quran underwent a complex genesis of omittance, selection and marginalization of other different compilations also known as codices. What is known as the Quran today was at the time of agreeing on a final version, the muṣhaf. The muṣhaf is part of the corpus of religious literature which was from a certain time consolidated and considered as a final collection of literature that was meant to be the source for all future religious formulations of faith. This process of closing the collection and formulation of secondary literature such as hadith and sunna results for Arkoun in an authoritative codex, namely the Official Closed Corpus (OCC). With regard to the muṣhaf we can assume Arkoun refers here to the 'Uthmanic text, a consonantal script (scriptio defectiva) lacking punctuations. ${ }^{13}$ Important for us is that Arkoun recognizes the Quranic text as a product of distortion, omission and selection. It seems imperative for Arkoun to mention that other existent versions next to the OCC were destroyed, "in order to avoid feeding dissent about the authenticity of the revelations selected." ${ }^{14}$ Indeed, Islamic tradition has not only one but different accounts of the Quran's compilation process. One common version is described by Welch, Paret and Pearson:

'Uthmān obtained the "sheets" from Hafșa ${ }^{[15]}$ and appointed a commission consisting of Zayd b. Thābit and three prominent Meccans, and instructed them to copy the sheets into several volumes following the dialect of Kuraysh, the main tribe of Mecca. When the task was finished 'Uthmān kept one copy in Medina and sent others to Kūfa, Bașra, Damascus, and, according to some accounts, Mecca (Gesch. des Qor. , ii, 112 f.), with an order that all other copies of the Kur'ān were to be destroyed. ${ }^{16}$

\footnotetext{
Arkoun, Rethinking Islam, 35.

al-lawḥ al-maḥfūz

What I call exceptionality Arkoun terms infallibility and superhuman.

10 Arkoun, The notion of Revelation, 65-66/ Arkoun, Rethinking Islam, 35.

1 Böwering, Recent Research on the Construction of the the Qur'ān, 82.

12 Welch, Paret, Pearson. "al-Kur'ān", EI; Krawulsky in: Eine Einführung in die Koranwissenschaften mentions also the role of Zayd b. Thabit. She refers to Ahmad Hanbal's Musnad, 127.

13 Note: Also of this kind, different versions of the proclaimed officially closed mușhaf existed.

14 Arkoun, Rethinking Islam, 35.

15 Hafșa was the daughter of 'Umar, the second so-called righteous caliph in Sunni Islam. She has also been one of Muhammad's wives.

16 Welch, Paret, Pearson, "al- Kur'ān", EI.
} 
Even though this account is one of the more traditional ones, neither Western scholarship nor Islamic theologians agree on only one possible version. ${ }^{17}$ Whichever compilation story Arkoun has in mind, it could be any account that states a selection or even distortion process. For us now it is central to see that Arkoun seems to take it as a given that destruction of Quranic text material took place. Arkoun seems to be aiming at evoking awareness among contemporary readers and students of the Quran, that there existed marginalised versions and the reason for excluding them from the canon might have had other reasons than divine intentions: practical, political, social purposes. Arkoun contends that the mușhaf was over time perceived as entailing God's word per se, which emanated right from the mother of the book:

Politically, in the absence of democratic mechanisms, the Qur'an plays an indispensable role in the process of legitimation in the new states. Psychologically, ever since the failure of the $\mathrm{Mu}^{\mathrm{c}}$ tazili school to impose its view of the Qur'an (mushaf) as created by God in time, Muslim consciousness has incorporated the belief that all the pages bound together as mushaf contain the very Word of God. The written Qur'an thus has become identified with the Qur'anic discourse or the Qur'an as it was recited, which is itself the direct emanation of the Archetype of the Book. ${ }^{18}$

Arkoun's emphasis of the history of the Quran as that of human manipulations allows doubt about how much revelation, or original divine word, the Quranic text really contains. Arkoun seems to deny any participation of the Divine in these manipulations, as it is sometimes put forward by Islamic teachings. Arkoun excludes what he considers mythological elements like the idea of Jibreel and Muhammad editing the text together, or that God gave Muhammad's followers superhuman memories. As an example of this belief in the latter notion I cite contemporary hadith-scholar Fazlur Rahman Azmi who in his essay Shabe Bara'at counts these 'exemplary' memories amongst the criteria for hadith-authenticity. He writes that "Allah Ta'ala endowed certain chosen servants with exemplary memories; Enabling them to memorise thousands of narrations with their chain of narrators; [...]." ${ }^{19}$ While Azmi writes here in the context of the nature of hadith transmission, it does seem representative of the view against which Arkoun is reacting with regard to the transmission of Quranic wording. I presume that those contemporaries who transmitted Quranic verses also partially transmitted sayings of the Prophet. The belief in the infallible memories of Muhammad's followers Arkoun regards as part of the mythological consciousness. His emphasized scientific perspective does not want to ignore the mythological but - in the course of a "welcoming sort of rationality"20 - wants to recognize these fabled aspects of the Islamic depictions as psychological components of the imaginary of human thinking. ${ }^{21}$ Also in need of socio-psychological analysis are certain religious notions that seem to have primarily social functions. For example he makes clear that the establishment of the first so called authoritative compilation (mușhaf) aimed re-eminently at uniting and binding the Muslim community. This is why in the process of text compilation social and psychological factors play a role. Theological constructions for justifying these concepts such as the muṣhaf and the infallibility of the chain of transmission must be read with one eye on social and political aims. I conclude that even though Arkoun rejects the idea of the infallibility of the sahāaba's memory, his perspective on the Quran regarding different accounts of alteration, compilation and editing of the Quranic texts finds support in the Sunni tradition. Surely this view of the history of the Quranic text seems to take on critical features which greatly exceed what the tradition would assert.

\section{Deliverer of haqq and Being-in-the-World}

17 Welch, Paret, Pearson, "al- Kur'ān", EI.

18 Arkoun, Rethinking Islam, 36.

19 Azmi, Shabe Bara'at - The Fifteenth of Sha'baan in the light of Qur'aan \& Hadeeth, 3.

20 Arkoun, Rethinking Islam, 37.

21 In other words such mythological notions must be analysed via the application of the anthropological category imaginaire. 
Arkoun believed that the way Muslims shape their lives, is partially influenced by standards and world views which are derived from Quranic interpretations. In this way Arkoun affirms the centrality of the Quran for faith and existence in the Muslim world. The idea of the Quran as underlying current for numerous social phenomena is reminiscent to Arkoun's idea of religion as a force which penetrates societies. Quranic interpretation Arkoun links to what he calls the hegemonic reason, which is the dominant thinking at a certain time and place in a society. The hegemonic reason puts forward standards of life, which instruct social conduct and decision making. These standards embody what is held to be true about the world, God and his laws. Even though Arkoun grants the Quran and hence religion importance, and makes them a central theme in his analysis, he is still critical of a reductionist view that says the Quran and its readings are responsible for all occurrences in the Islamic world. In Arkoun's view, this wrongly reduces the complexity of human thinking to a minimalistic world view, which is of no help to the current affairs of our all being-inthe-world. Arkoun employs the expression being-in-the-world to express the existential importance of social systems such as religions. ${ }^{22}$ It is this context of explaining the Quran's ability to give meaning to our being-in-the-world in which the engagement with the text (its reception and exegeses history) should take place. In other words, what Muslims believed to be true and worth basing their decisions on should be subject to investigation. In that one also discovers the development and changes of mentalities throughout history. Hence Arkoun hopes for a sketching of the history of mentalities (Mentalitätsgeschichte). This latter idea entails also the study of values and their generation throughout human history. Obviously the study of mentalities and values goes beyond the study of Islamic culture, which only serves as a starting point for Arkoun's overall research proposals. Thoroughly scrutinizing the evolution of values will lead to a broader comprehension of claims to truth and faith. Now in the context of Quranic studies which interests us here, he points out the role of the Arabic term for truth, al- haqq and its reference to the book Quran itself, the Quranic message, Islam and God. ${ }^{23}$ Arkoun reckons that the function of the Quran to shape humankind's being-in-the-world necessitates that the Quran delivers truth (truth-right/haqq). Faith emerges then in the course of people's appropriation of what they hold to be true according to the Quran (or other religious scriptures). Along the line of haqq one can study the history of values and mentalities, as mentioned before. In all this the role of the Quran is that of a deliverer of truth concepts, therefore of faith and subsequently of social standards. But why does Arkoun think the Quran has the power to deliver all this? This is for one reason because of the Quran's selfproclamations as God's message of the ultimate monotheistic religion and as the final truth. Arkoun then writes on haqq from a more theological perspective: "[...] the term haqq, a concept expressed in the Qur'an [and notably enriched by the great mystics of the classical period. The term 'truth' (haqq) refers at the same time to truth, justice, what is right, the actually real." ${ }^{24}$ It constitutes a new set of values, or from the devotee's view: it restores the original values that make the covenant (mithāq) between Allah and its people. From this finalizing perspective the Quran calls for an Islam

22 The concept of being-in-the-world occurs in Okakura Kakuzo's The Book of Tea in which he discusses the Chinese perception of Taoism as the "art of being in the world.” It also expresses an idea formulated by Heidegger in his philosophy of being (Seinsphilosophie). Heidegger used the expression Das-in-der-Welt-Sein, which means literally that-in-the-world-being. Arkoun occasionally refers to Heidegger's metaphysics but does not say whether he derived this term from Heidegger. Arkoun might have derived it from his readings of Dilthey or Foucault who utilize Heidegger's philosophy.

23 The term al-haqq appears numerously in the Quran with different connotations and in different contexts. The Corpus Quran Project detects 191 occurrences of al-haqq (and in its derivations; http://corpus.quran.com/search.jsp?q=truth\&s=1\&page=1).

24 Arkoun, "The Reflexive History of Thought Seen as a Problematisation of Truth," 14. On page 1 of this (to my knowledge) unpublished essay, Arkoun cites the following as an introduction: " "However, the number one obstacle to the search for light is quite probably the will to power, the desire to show off one's virtuoso abilities or to provide a shelter against too evident objections. Truth is a limit, a standard which is higher than individuals, most of whom harbour a secret animosity against its power» André Lalande, Vocabulaire technique et critique de la philosophie” Préface, PUF 1926.” 
which equals truth as such and is hence superior to other religions, which if they contain truth at all entail a distortion of truth. Islam hence is also referred to as $d \bar{i} n$ al-haqq, the true religion/belief. When studying Islam and the Quran the concept of truth-right must be recognized as a fundamental theological idea with consequential social effects. Although Arkoun claims that the Quran entails the mechanisms for having impact on people and societies, he does not yet explain how exactly these mechanisms operate. He understands himself more as an ambassador for developing a methodology of academic rigour in this regard.

\section{Multi-Level-Transition}

Arkoun believes in a multi-level involvement of the Quran with human affairs. Although his account reminds us of the idea of interconnectivity of the Quran, Arkoun approaches it from a different perspective. If one considers, as Arkoun does, not only the written text - which is complex literature by itself - but also its emergence and reception by human thought, it can be seen that human rational engagement with the Quran is actually shaping human thought and society. Arkoun's conception of the relationship between Quran and person avoids any admitting of revelation having been an actual event. Arkoun's research draws the human understanding of 'what is perceived as revelation' in the foreground.

Arkoun notices - as does Islamic tradition - the difference between the time of revelation and the following periods. We know that the classical categorization of verses with regard to the geographic whereabouts of the Prophet in either Mecca or Medina is programmatic for the acceptance of the idea of condescension. ${ }^{25}$ Arkoun accentuates such historical developments of the text. For instance he distinguishes between Quranic reality/QR (fait quranique) and Islamic reality/IR (fait islamique). In addition, it is important for him to distinguish the oral from the written Quran. Introducing the concept of QR makes explicit the chronological gap between the instance of revelation and the following period IR. QR refers to what was manifested in the course of history of what Muslims generally believe to have been revelation, sent by Allah to Muhammad ibn Abdullah to restore monotheism. ${ }^{26}$ In the QR takes place the act of revelation and the discourse between text, Muhammad, and the first follower generation. Arkoun does not yet speak of 'text' regarding the initial situation between Muhammad and the Divine. He prefers the term 'discourse.' The Quran understood as initial discourse also includes the first meaning production by the people (al-nās or the final addressee). This first meaning production is partially reflected in the Quran's reaction to certain responses by the first audience towards Muhammad's utterances. Since Arkoun denies the possibility of researching the communication between the divine sphere and Muhammad, explaining the term revelation will have to entail a discussion about the discourse on the horizontal level (Prophet-Text-People) which takes place in the physical realm. One characteristic of QR - if one assumed a divine agent as communication source - is immediacy on the vertical level. On the

25 The Arabic word for 'to descend' is nazala and its derivation tanzīl (which means 'something sent down') are used to term the process of message transmission between God and the angel Gabriel.

26 Arkoun prefers to refer to the Islamic Prophet Muhammad with his worldly name in order to avoid his research to be linked to a specific theological a priori. With this, Arkoun wants to underline the character of his work as historical research. Günther describes him: "Er begreift sich als Historiker bzw. historien penseur der islamischen Geistes- und Ideengeschichte, der eine Perspektive der philosophischen Vernunft einnimmt.” Günther, Mohammad Arkoun, 218). Arkoun writes: "By the Qur'anic fact I mean the historical manifestation, at a time and in a precise socio-cultural milieu, on an oral discourse which accompanied, for a period of 20 years, the concrete historical action of a social actor called Muhammad ibn Abdullah.” (Arkoun, "Present-Day Islam,” 58.)/ Günther writes that the 'fait coranique' is "God's appeal to human conscience, which took place in a language and in the context of particular economic, social, ethical and political experiences in the Arabic peninsula of the 7th century, in order to make alert the existential conditions of a belief in the one God." (Günther, Mohammad Arkoun, 269)/ "The concept of the One God comes to be reworked, not for the sake of its own content, but in order to repudiate, right from the start, the manner in which it is asserted by other 'Peoples of the Book'. [...] The Jews and Christians are called upon to correct their errors (in other words, to do tawba) in the same vein as the idolaters or polytheists are required to do.” Arkoun refers here explicitly to sura 9. (Arkoun, "Revelation Revisited", 31). 
other hand QR is shaped by communication of three parties: the speaker (God/ Jibreel), the first (Muhammad) and the final addressee (the people: al-nās). The term 'Quran' refers within QR to an oral transmission of messages among those parties. More precisely it means a transmission of messages, uttered by Muhammad and presented as God's words, to al-nās. The investigation of the actual encounter between the divine sphere and Muhammad is out of the scope of Arkoun's proclaimed research realm.

Hence the transmission between God and the final addressee will in the following be referred to as the transmission between Muhammad and the people, thus referring to the realm that is a possible research object according to Arkoun. He describes the QR: "For a period of at least twenty years there occurred an explosion of values, a kind of continuous creativity in which symbolic language constantly elevated and opened social and political behavior to the realm of transhistoric [sic!] meanings. This was the role of Qur'anic discourse, which is always to be distinguished from the hadith, [...]."27 When Arkoun uses the term 'text' in discussions about this initial situation, it means the divinely initiated oral utterances of Muhammad. I read from Arkoun's reflections, that he renders it possible that some of the utterances were already put into writing within QR. Still the significance of the writing is minor since memorization and orality were - in contrast to writing the common tools of transmitting information within that given cultural realm. ${ }^{28}$ It seems Arkoun's scholarly perspective avoids a detailed discussion about tanzīl or wahy, since he is more interested the meaning of revelation for society. ${ }^{29}$

Following QR there was the Islamic Reality (IR), which followed the end of revelation and was marked by the compilation of a variety of written texts meant to resemble the oral discourse or (in theological terms) God's words. Those compilations became a new authoritative reference point in the course of establishing the upcoming religion. In a second stage IR is marked by the gradual replacement of the oral discourse with theological interpretations of written texts. As we can see, these developments within the formative period of Islamic religion raise certain questions which lead beyond the mere problem of authority. We will not engage in Arkoun's project of deconstructing Islamic thought (the endeavour he is most known for), but at this point we need to become aware that the two concepts QR and IR and their distinction are the backbone of Arkoun's critical investigation into Islamic thought. This is because the distinction between QR and IR admits three crucial transitions in the history of the Quran. I put them this way: oral text evolution within a multiple-parties discourse, transition of authority from orality to writing, and transition from authority of text to authority of interpretation.

According to Arkoun these transitions have to be explored by applying adequate sorts of disciplines (e.g. history, anthropology, philology, linguistics, discourse analysis, psychology, sociology). Those can and sometimes must be intertwined, resulting in pluralistic, broad approaches to the Quran, Islamic thinking and cultures. It seems with the demand of multiple approaches Arkoun wants to do justice to the complexity of the research objects. The first transition (the evolution of an oral text within a multiple-parties discourse) marks the actual emergence of what will later be believed to have flowed into the written accounts. The concept of this transition recognizes the Quran's emergence in connection to the linguistic system of seventh-century Arabia, its penetration by symbolic language, in the socio-political conditions of Oriental cultures, in a realm of world

27 Arkoun, Rethinking Islam, 44.

28 Hawting, "Pre-Islamic Arabia and the Qur'ān", EQ; Kermani points out that the oral character of the Quran is relived in the recitation of the Quran. While the performance of recitation the listener absorbs the Quran not via reading scripture but by listening to it. Therefore the Quran has also today high significance in its orality. Kermani, Gott ist schön, 208-9.

29 Dispite his distanced approach to the phenomenon 'revelation' Arkoun does not consider using a different expression (although he sometimes speaks of 'notion of revelation'). In the analysis of Arkoun's thought I suggest to refer to the Muhammad's first proclamations (which were presented as revelations from God) as 'initiated oral utterances.' This expression leaves open the source for the initiation and hence does justice to Arkoun's stance. As we have seen also he leaves out the discussion about whether and how Muhammad was inspired but at the same time considers a psychological examination of the experience of revelation. The expression initiated oral utterances avoids the inclusion of a specific divine agent, as portrayed in this specific religious tradition. 
perception infiltrated by myths and expressed by rites and certain practices characteristic of religions in oral societies.

\section{From Orality to Written Authority}

The second transition (from orality to writing) raises the question of the authority of the written in contrast to the oral Quran, or vice versa. The religious environment of QR was mostly functioning on the basis of oral transmission of general as well as metaphysical knowledge. Of course, also the art of Arab poetry was mainly presented in an oral event. So the authoritative concept of oral transmission of knowledge was known to the first audience. This does not mean however, as Arkoun points out, that the new religious message's legitimation was not subject to substantial challenges and critique by the first hearers. The mere fact of its oral nature might not have been a sufficient tool of persuasion and authority. However, at least it established a common ground of communication and understanding, thanks to it being a broadly familiar concept.

With the approval of a written Quranic text and the marginalization of other written versions, and especially in the course of struggling to proclaim one final ultimate text, the fact that the Quran was originally an oral communication act gradually receded into the background. The Quran primarily known as the oral discourse transformed into the mușaf, which is "in the current linguistic sense of that term" what is referred to as the Quran. ${ }^{30}$ The third transition (from authority of text to authority of interpretation) was fuelled by the concept of a mușhaf which generated a tendency to claim that since there is one Quran it has only one meaning. This claim will lead to what Arkoun targets as 'instrumentalization of the Quran'. Still, until now Arkoun has not given convincing reasons for believing that the awareness of the original orality of the Quran could avoid such instrumentalization. Nevertheless, it is understandable that the OCC came to represent unity and totality, freedom from doubt, and underwent a process of sacralisation. ${ }^{31}$ The sanctified status of the Quran made it the central textual source (in contrast to other, what I call 'secondary sources' like hadith and sira) for the formulation of Islamic faith. The artificial construct of an OCC supported the promotion of the Quran as the true, final and only scripture. In consequence it "became an object of infinite interpretation aimed at all believers [...]."132

The Qur'ān as an object of research is a collection of initially oral utterances put into writing in historical conditions not yet elucidated. These utterances were then elevated, by the industry of generations of historical figures, to the status of a sacred book which preserves the transcendant [sic] word of God and serves as ultimate and inevitable point of reference for every act, every form of behavior and every thought of the faithful, who themselves are to be considered as communally interpreting this heritage. ${ }^{33}$

This shift, from addressing a limited circle of people at a certain time in history, to then addressing all humans at all times, is of utmost significance. ${ }^{34}$ It becomes clear that this transition from orality to writing is related to our above exploration into Arkoun's stances on the corruption of the Quranic text. Arkoun's concept of the compilation allows for possible meaning alteration, due to different consonant spellings in different versions of the mușhaf. Although Arkoun refers to only one final compiled muṣhaf the anticipated practice of omission and selection makes it likely that the text was

30 Arkoun, Rethinking Islam, 41.

Arkoun. "Revelation Revisited,” 2; Tilman Nagel mentions the sacralization process within Islamic tradition from the 11th century on. Cf. Nagel, Allahs Liebling, 115.

32 Arkoun, Rethinking Islam, 37-8.

33 Arkoun, "Contemporary Critical Practices and the Qur'an."

34 Hawting discusses the crucial changes the Quran must have brought about after its emergence in Arabia. He points out the tension (which is also a question of debate within Rahman's Quran understanding) namely how specific messages can entail universal meanings: "There is a certain tension between the idea that the Qur'ān is a revelation relevant for and applicable to all peoples and all times, and the view that at least some of it was revealed with reference to a specific society and time and to particular incidents in which the Prophet was involved." Hawting, Pre-Islamic Arabia and the Qur'an. 
altered. ${ }^{35}$ It appears on a closer look that Arkoun may refer to the idea of a muṣhaf rather than the actuality of one. Here I must stress that the OCC includes of course also other literature, secondary to the Quran, but which is also believed to be finally closed by the various orthodoxies. But the mușaf is, of course, part of this OCC. Arkoun seems to say that most Muslims are kept in ignorance of the textual variations of the mușhaf of which Muslim scholars are aware. However, Arkoun himself is still oversimplifying the tradition. ${ }^{36}$ Despite Arkoun's apparent awareness of the history and variants of the Quranic texts, he does not elaborate on it. Before the background of these different accounts of the history of the Quranic text, Arkoun's term 'OCC' seems for his purposes a practical reduction of what has probably been a complex phenomenon.

In conclusion, Arkoun's thought on the genesis and cultural significance of the Quran carry important implications for the study of the Quran, a re-evaluation of its authority, as well as the study of Islamic cultures. Mohammad Arkoun recognizes the history of the Quranic text, an originally oral event, a product which comprises modes of expression common to its environment of its emergence, and which was collected into a muṣhaf and subsequently sacralised through tradition. With this, Arkoun's account of the Quran allows for the idea of the createdness of the written text, which only represents one of various possible versions of the original oral discourse. Despite the obvious importance of the Quran and its exegesis throughout the Islamicate realm, Arkoun does not reflect on whether the Quran is 'rightly' considered to deliver a guideline for humankind. He rather engages with the question of how the Quran's language mechanisms have interacted with the demands and concerns of the interpretive communities, and with that has created and continues to shape multiple Islamic social realities.

Arkoun's rethinking of the Quran provides for a range of disciplines to be applied to the study of the text. Such methodological opening potentially leads to various understandings of the text itself. Furthermore, this epistemological broadness enables a fresh look onto the cultures, who have interpreted the Quran and through this have so profoundly shaped their societies.

35 Zwettler, The Oral Tradition of Classical Arabic Poetry, 122-4.

36 This understanding of Arkoun's notion of the muṣhaf as part of the OCC would also represent a more adequate stance with regard to the factual existence of Quran text variations today (e.g. different qiraat (readings/citation methods), which differ in harakat (vowel pointing system) but not in $i$ jām, (diacritics)) and in the past even after the possible compilation ruling of 'Uthman. The record of variants of reading the Quran shows that even those were not merely different in harakat but show occasionally variants in the rasm, the base structure of consonants. Cf. Donner in his article "The Quran in Recent Scholarship" shows that also some variants of qiraat appear to have different rasm (42). As an example he refers to: "Paret, citing A. Fischer, in EI2, 'Kirā'a.' A salient example is found in the text of Q. 3:19, where for the phrase "inna l-dīn 'inda llāhi l-islām" we find in Ibn Mas'ūd's reading "inna l'dīn 'inda llāhi l-ḥanīfiyya" (Jeffrey, Materials, 32).” (footnote 61 on page 50) 